\title{
THE SUBSURFACE GEOLOGY AND RESERVOIR CHARACTERISTICS OF THE UPPER BAHARIYA RESERVOIR IN THE HAYAT/YASSER OIL FIELD, NORTHWESTERN DESERT, EGYPT.
}

\author{
Wafdy, R. ${ }^{1,}$ Selim, S. S. ${ }^{2}$, and Abu khadrah, A. M. ${ }^{2}$ \\ ${ }^{1}$ Department of Exploration, Khalda Petroleum Company, New Maadi, Cairo, Egypt. \\ ${ }^{2}$ Department of Geology, Cairo University, 12613, Egypt.
}

\begin{abstract}
The litho-stratigraphic cross sections, thickness variations and lithofacies of the Upper Bahariya reservoir (Upper Bahariya Member) are discussed to distinguish the shape, the extent of sedimentary basins and the environment of deposition. The studied Upper Bahariya reservoir shows that the Upper Bahariya Member top is coming higher at Yasser-06 well than the other three wells, which lies in the northeastern part of the study area. Furthermore, the maximum thickness of the Bahariya Formation occurs at Hayat-12, while the minimum thickness occurs at Hayat-17 well. The facies triangle lithologic model of the Upper Bahariya Member shows, the predominance of calcareous shale facies in most of the studied wells which change to shaley sand in the central part at Hayat-12 and Hayat-14 wells. These facies reflect a shallow marine environment grading from tidal-dominated estuarine channels to wave-dominated shoreline associating with lagoons or bays. The petrographic analysis shows that, there is a variation in the reservoir quality based on the detrital clay components and diagenetic processes.
\end{abstract}

Keywords: Subsurface Bahariya formation, Reservoir characteristics, Hayat/Yasser oil field, Western Desert, Egypt.

\section{INTRODUCTION}

The Western Desert has numerous oil potentialities, the Hayat/Yasser oil field lies in Khalda Concession which located in the northern part of the Western Desert. The Khalda Concession is located approximately $100 \mathrm{~km}$ south of the Mediterranean Coast and approximately $300 \mathrm{~km}$ west of Cairo. Within the Khalda Concession, there are four main fields; Salam, Kenz, Hayat and Yasser. The area of study lies at $4 \mathrm{~km}$ south of the Kenz field and 5-6 km from Shrouk along the Khalda Ridge. The study area is located between Latitudes $30^{\circ} 30^{\prime}-30^{\circ} 56^{\prime} \mathrm{N}$ and Longitudes $26^{\circ} 36^{\prime}-27^{\prime} 00^{\prime} \mathrm{E}$ (Fig. 1). The general structural and stratigraphic aspects of the Western Desert have been the subject of many studies, such as Amin (1961), Said (1962 and 1990), Norton (1967), Dia El-Din, (1974), Parker (1982), Meshref (1982), Kerdany and Cherif (1990), Shalaby et al. (2000). The generalized stratigraphic column of the Northern Western Desert includes most of the sedimentary succession from the Pre-Cambrian basement complex to Recent (Fig. 2), with total thickness, despite some anomalies, increases progressively to the North and Northeast, from $6000 \mathrm{ft}$ in the south to $25000 \mathrm{ft}$ along the coastal area. The main producing horizons in the Hayat/Yasser oil field are Cretaceous reservoirs; Abu-Roash G, Upper and Lower Bahariya and Alam El-Bueib formations. The Bahariya Formation is one of the most prolific hydrocarbon producing formations in the Western Desert, especially in the Khalda concession. The Cenomanian Bahariya Formation consists mainly of fine to medium-grained quartizitic sandstone, colorless to pink, medium to coarse-grained with thin streaks of shale and carbonate. It represents a gradational fining upwards phase to the overlying marine carbonates and shales of the Turonian - Coniacian Abu Roash Formation and underlying Albian Kharita Formation, which is composed of clean medium to fine-grained, well-sorted sandstone, separated by shaly and silty intercalations of shallow marine origin. 
Wafdy, et al

\section{GEOLOGICAL SETTING AND PREVIOUS WORK}

\section{Tectonic framework}

The Mesozoic was an Era of great tectonic and environmental change in the North African region, as was the case for much of the world. Egypt was subjected to numerous environmental and continental alterations that influenced and shaped the coastal areas, and created tectonic depocenters. This was especially the case in the northwestern regions of Egypt where there were plate motions between the African and Laurasian plates (Sestini, 1984). This tectonic or structural history recorded in the sedimentary rocks buried below the desert sands, the thick Nile delta and sedimentary deposits filling the petroleum basins of Egypt.

Fig. 1: Basins distribution map showing the location of the studied wells.

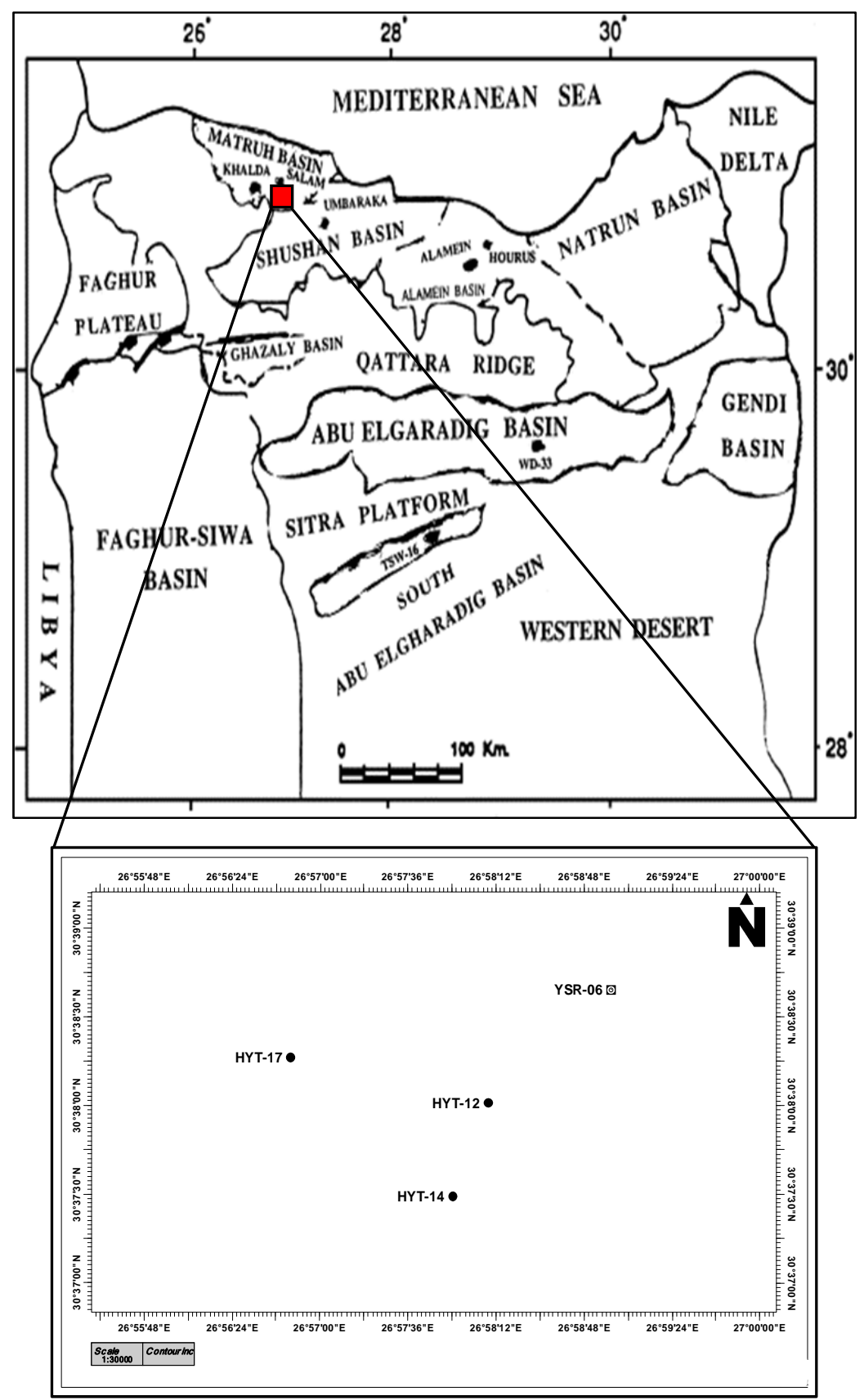


The subsurface geology and reservoir characteristics of the Upper Bahariya Reservoir

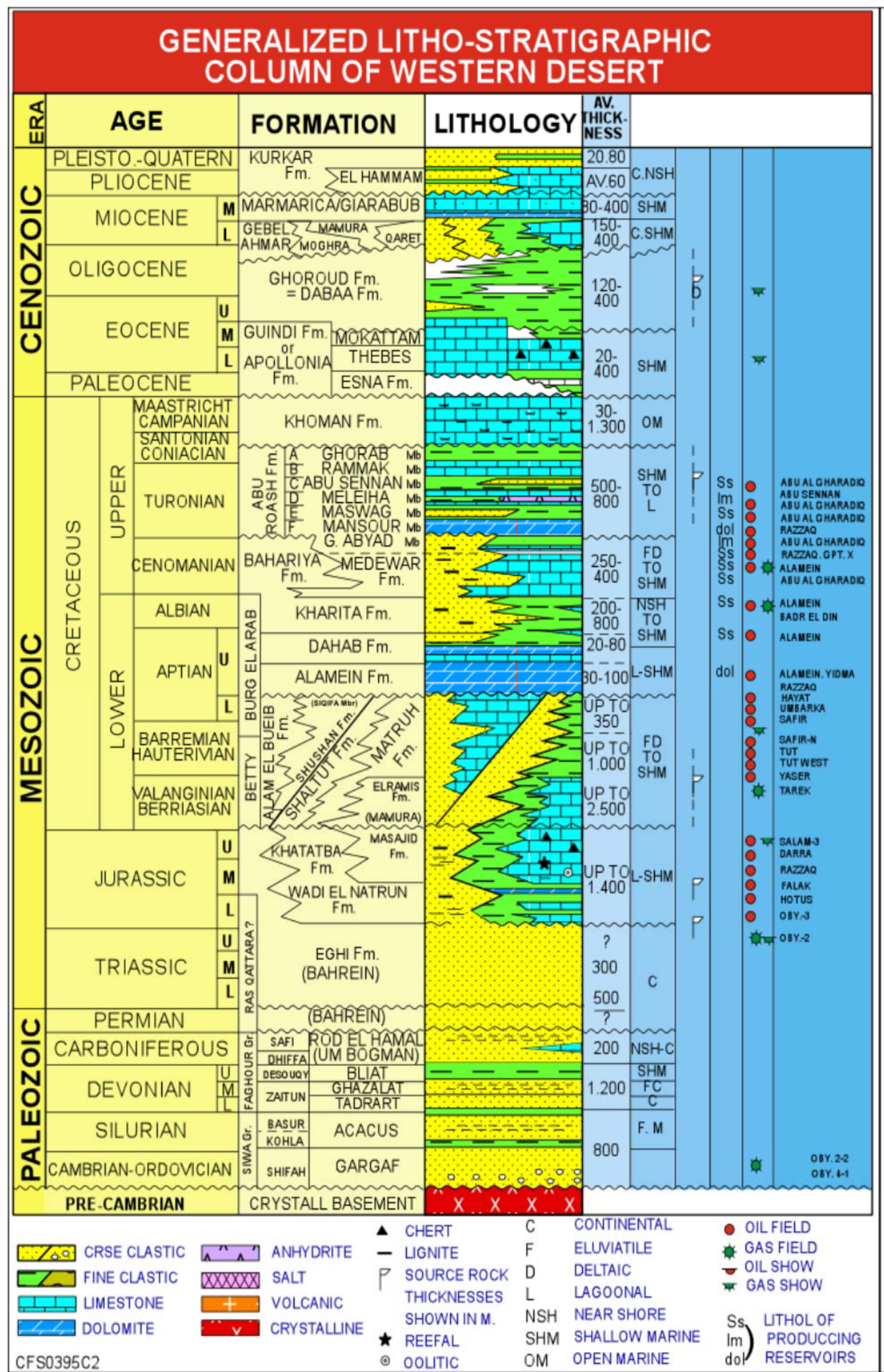

Fig. 2: Generalized stratigraphic column of the North Western Desert, (After Schlumberger, 1995)

The Mesozoic and Cenozoic Basins in Egypt (Fig. 3) extended across northern Egypt to Sinai (Moustafa and Khalil, 1990). Located within an overall northward-thickening continental passive margin they form a series of discrete E-W to ENE-WSW and NE-SW oriented half-graben basins 
(Sultan and Halim, 1988; Emam et al., 1990; Taha, 1992; Moustafa, 2008; Bevan and Moustafa, 2012) and includes Shoushan, Matruh, Kattaniya, Alamein, and AG Basins. The major faults crossing northern Egypt in an ENE-WSW direction with the up-thrown blocks forming nonprospective ridges and the large down-dropped blocks forming the petroleum basins of the Western Desert. The wrench or lateral movements that occurred along these faults during the Cretaceous formed large sedimentary basins, ridges, and produced smaller faults running parallel to large faults (Meshref, 1996).

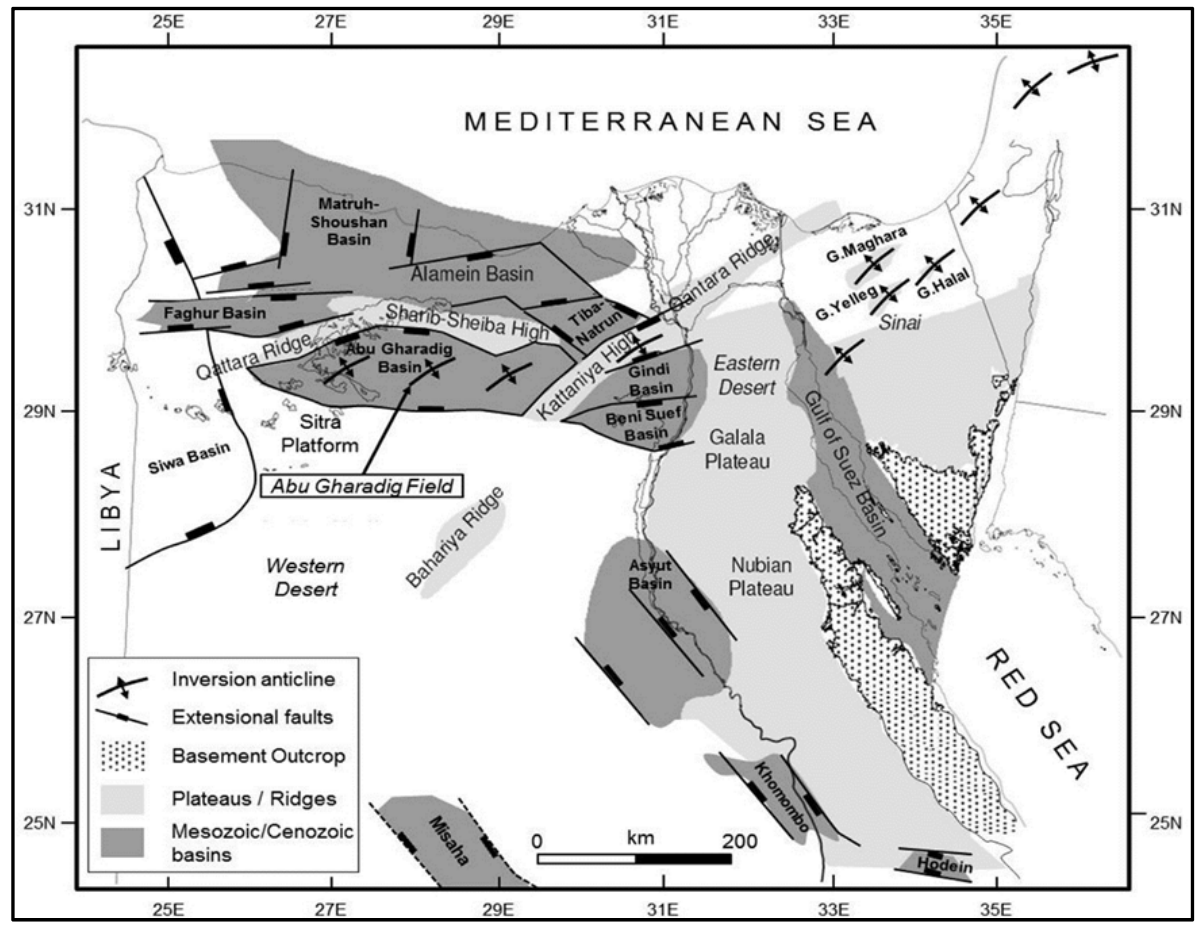

Fig. 3: Mesozoic and Cenozoic Basins in Egypt (modified after, Moustafa, 2008; Bevan and Moustafa, 2012; Dolson et al., 2001. Upper Egypt basins added after Bosworth et al., 2008).

The study area is located between two major faults (Fig. 4); one in the northeast (Fault-1) and the second in the southwest (Fault-2). The extinction of these faults is WNW-ESE and the area of study is located at the footwall related to the normal fault system. The north Western Desert was tectonically active through Jurassic and Cretaceous times (Hantar, 1990). Moussa (1986) stated that in the AlbianCenomanian, the Matruh and Shushan Basins (Fig. 1) were connected by a narrow seaway to form a large intra-cratonic basin. Through the Turonian-Santonian, the Shushan and Matruh Basins continued to develop as a single basin trending almost North-South with a further extension to the East. During the Senonian, the Shushan Basin separated from the Matruh Basin. In the Early Cretaceous, the Matruh Basin was a site of a rapid and continuous subsidence. It was uplifted and eroded in the Late Cretaceous and Early Tertiary (Moussa, 1986).

\section{Stratigraphic framework and paleogeography}

Most research carried out on the Bahariya Formation has focused on the neighboring Meleiha Field. Metwalli et al. (2000) separated the Bahariya Formation within the Meleiha Field into two main facies associations: i) tidal flat and tidal channel facies association and ii) nearshore, shallow marine facies association. They designated twelve different depositional processes to these facies in order to describe the paleo-environmental settings of the Upper Bahariya Formation. Depositional environments selected to represent the tidal flat and tidal channel facies associations include: tidal channel, sand flat, mixed flat, intertidal zone, marsh-swamp, and mud flat The nearshore, shallow marine facies association consists of the following depositional systems: lagoon, shallow marine, marine shelf, shallow marine (storm lag), near shore (carbonate shoal) and marine. 
The subsurface geology and reservoir characteristics of the Upper Bahariya Reservoir

Fig. 4: Base map showing the correlation profiles passing through the wells.

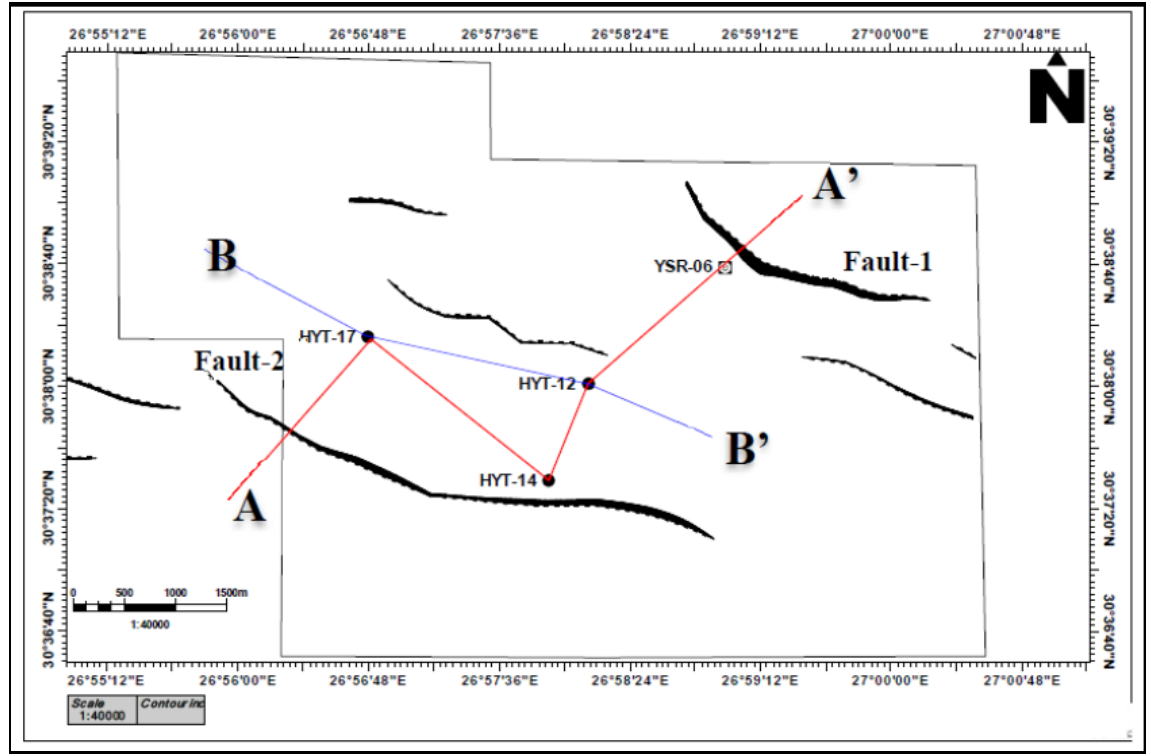

The Upper Bahariya Formation in the Meleiha area has established a variety of hypotheses. Kholeif et al. (1986) suggested a depositional setting of a marginal marine to shallow tidal flat setting. Elsheikh (1990) suggested a tidal flat environment grading upwards into a shallow marine shelf. Darahem et al. (1990) subdivided it into four units of nine zones including a range from a sub-tidal complex to a restricted marine shelf. Salah and Paradisi (1992) described it as a tidal flat and channel fill sand environment. Each of these hypotheses involves environmental conditions that are associated with shallow coastal settings and intertidal deposits.

The Bahariya Formation is divided into two units from bottom to top; the Lower and Upper Bahariya (Figs. 5A, B and C).

\section{METHODOLOGY AND DATASET}

This study was accomplished through the integrated interpretation of the available geological, petrographical and petrophysical data. The main database of the study comprises four cored wells (Hayat12, Hayat-14, Hayat-17 and Yasser-06) (Fig. 5A and Table 1). The analyses used to accomplish this study are summarized in the following points:

1) Core description, thin section investigation and SEM interpretation representative eight thin sections were prepared and investigated the selected samples from the studied wells. Also, five representative samples were selected for investigation by Scanning Electron Microscope (SEM).

2) Wireline log analysis using the available data (gamma ray, neutron porosity, density, resistivity and sonic).

3) Construction of isopach and facies maps in addition to geological cross sections and the correlation profiles for the various litho-stratigraphic units.

Table 1: Available data in the study area for the Bahariya Formation.

\begin{tabular}{|c|c|c|c|c|c|c|c|}
\hline \multirow[b]{2}{*}{ WELL } & \multicolumn{5}{|c|}{ WIRELINE LOGS } & \multirow{2}{*}{$\begin{array}{c}\text { SEM } \\
\text { Samples }\end{array}$} & \multirow{2}{*}{$\begin{array}{c}\text { Thin Section } \\
\text { Samples }\end{array}$} \\
\hline & $\begin{array}{c}\text { Gamma } \\
\text { Ray }\end{array}$ & $\begin{array}{l}\text { Neutron } \\
\text { Porosity }\end{array}$ & Density & Resistivity & Sonic & & \\
\hline HAYAT-12 & $\sqrt{ }$ & $\sqrt{ }$ & $\sqrt{ }$ & $\sqrt{ }$ & $\sqrt{ }$ & 2 & 2 \\
\hline HAYAT-14 & $\sqrt{ }$ & $\sqrt{ }$ & $\sqrt{ }$ & $\sqrt{ }$ & $\sqrt{ }$ & 1 & 3 \\
\hline HAYAT-17 & $\sqrt{ }$ & $\sqrt{ }$ & $\sqrt{ }$ & $\sqrt{ }$ & $\sqrt{ }$ & 2 & 2 \\
\hline YASSER-06 & $\sqrt{ }$ & $\sqrt{ }$ & $\sqrt{ }$ & $\sqrt{ }$ & $\sqrt{ }$ & & 1 \\
\hline
\end{tabular}

The integration of the petrographical and wireline logs data will be used to clarify the facies geometry and sedimentation pattern of the studied Upper Bahariya reservoir. 


\begin{tabular}{|c|c|c|c|c|c|}
\hline Code & Name & Parent & Background & Lines & Pattern \\
\hline 1 & SAND & & $\checkmark$ & v & 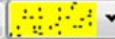 \\
\hline 2 & TIGHT SAND & & $v$ & r & $\therefore$ \\
\hline 3 & SILT & & $\checkmark$ & v & $=\div$ \\
\hline 4 & SHALE & & $v$ & v & $=$ \\
\hline 5 & Marl & & $\checkmark$ & r & v \\
\hline 6 & LIMESTONE & & $v$ & v & v \\
\hline 7 & DOLOMITE & & $v$ & v & ${ }_{1}{ }_{1},{ }_{2}$ \\
\hline
\end{tabular}

Fig. 5: Color code legend for lithological composition derived from well logs.
Fig. 5A: Structural correlation and stratigraphic succession for the studied wells from southwest to northeast.

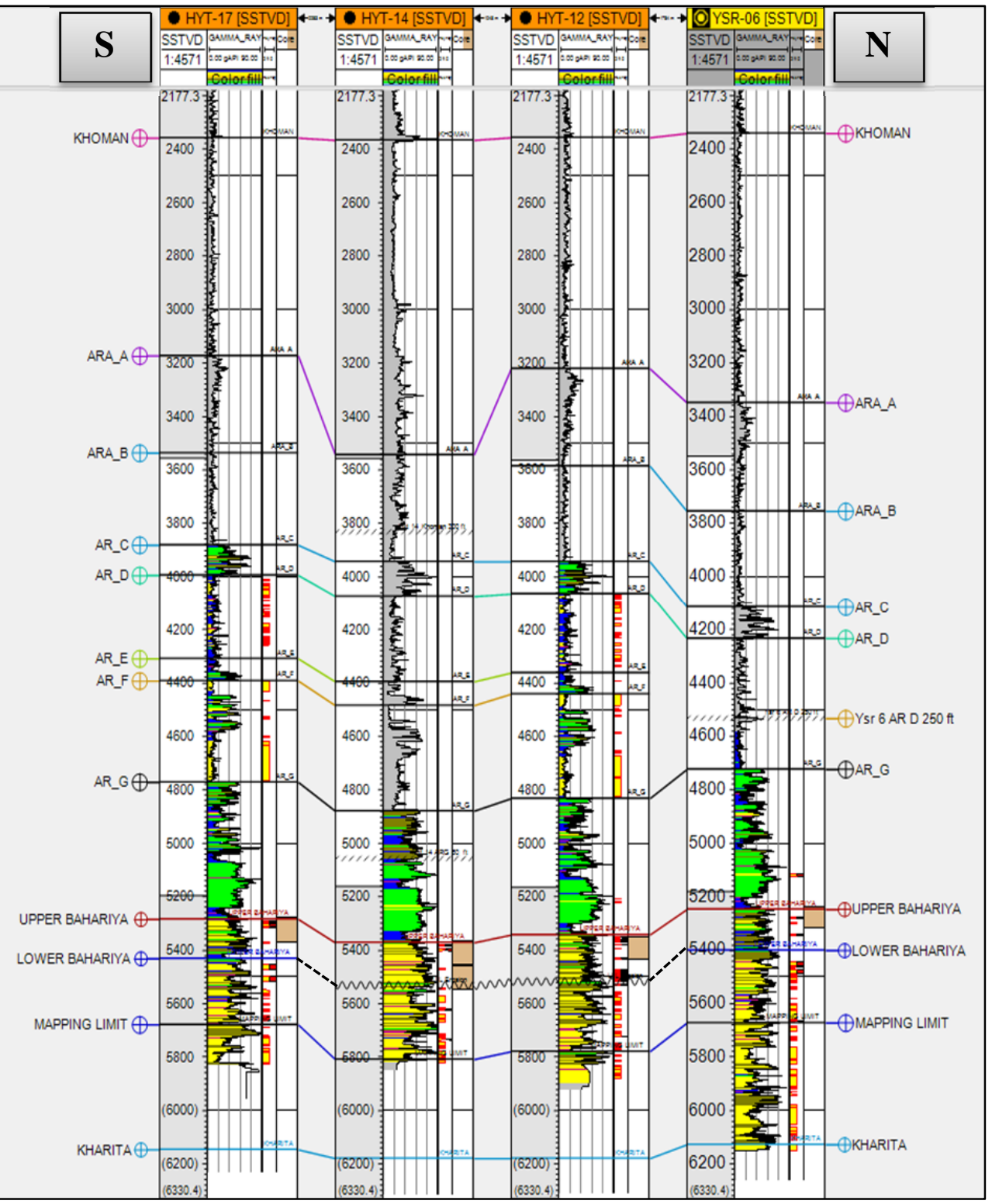

RESULTS AND DISCUSSION

\section{Facies maps of the Upper Bahariya reservoir}

Lithologically, the Upper Bahariya Member consists of very fine to fine-grained sandstone, siltstone, shale and streaks of carbonate, indicating shallow marine facies. The facies distribution map shows that the Upper Bahariya is characterized by calcareous shale facies in most of the studied wells and changes to shaley sand in the central part at Hayat-12 and Hayat-14 wells (Table 2). Figure (6) Illustrates the lithological distribution of the Upper Bahariya reservoir according to Krumbein and Sloss (1963). These 
The subsurface geology and reservoir characteristics of the Upper Bahariya Reservoir

facies reflect a shallow marine environment changing to tidal channel and tidal flat environment at the central part of the study area (Fig. 7a).The Upper Bahariya reservoir shows variable thickness, which is related to the tectonic activity during the deposition of this unit (Fig. 7b). The maximum thickness of Upper Bahariya sediments reaches $176 \mathrm{ft}$. in the Hayat-12 well, while the minimum thickness is $147 \mathrm{ft}$. in the Hayat- 17 well. The thickness of the Upper Bahariya increases at the central part of the study area in Hayat-12 \& Hayat-14 wells (Table 3).

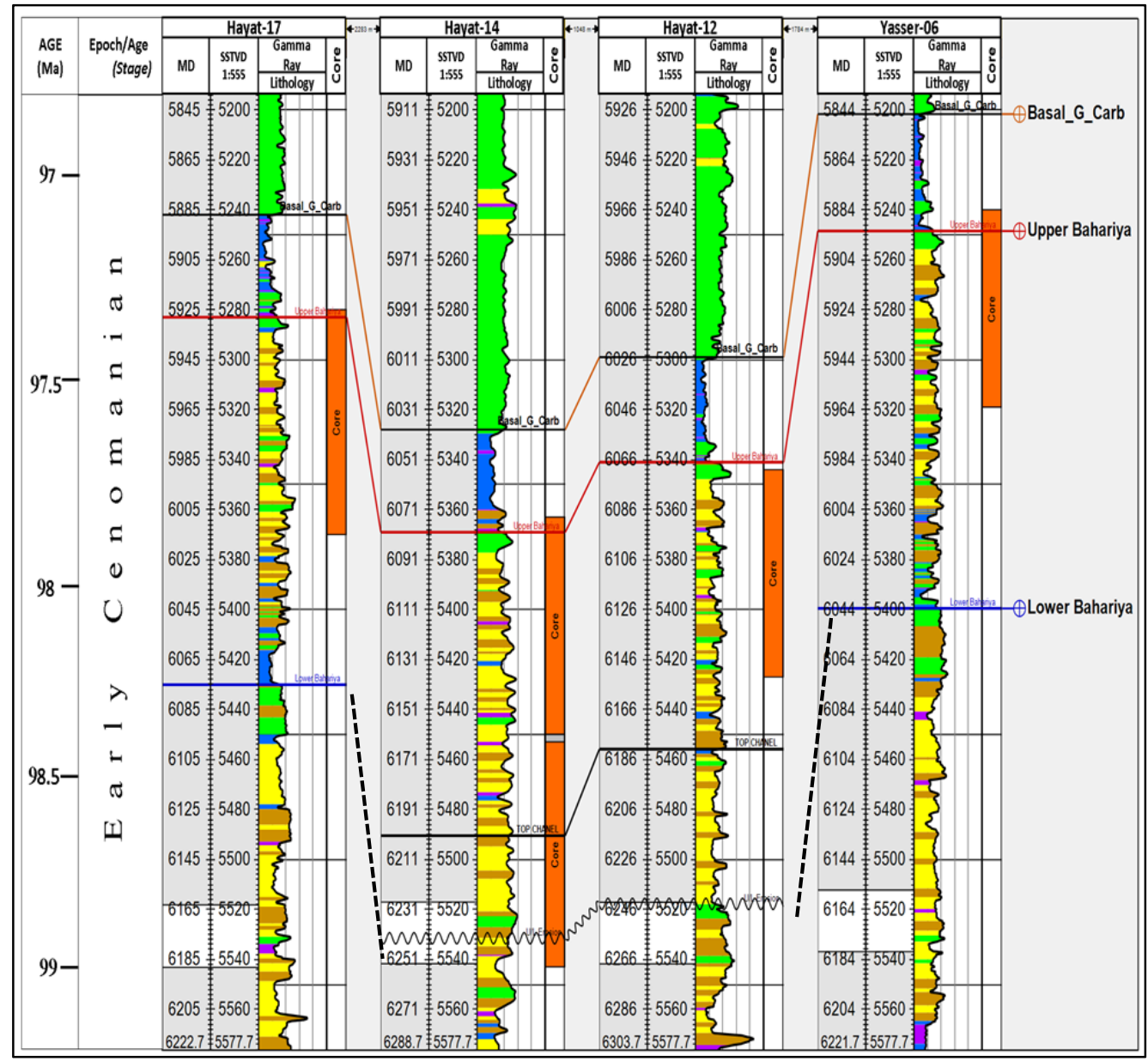

Fig. 5B:

Structural correlation passing through the profile A-A' (Fig.4) for the studied wells with time.

Isolith maps were constructed for the Upper Bahariya reservoir to show thickness variation in the single rock type, to interpret the environmental conditions during the deposition of sediment and to elucidate the geological history.

Table 2: Limits and characteristics of lithologic groups by (Krumbein and Sloss, 1963).

\begin{tabular}{|c|c|c|c|}
\hline Group Name & $\begin{array}{c}\text { Clastic ratio } \\
\text { limit }\end{array}$ & $\begin{array}{c}\text { Sand-Shale } \\
\text { Limit }\end{array}$ & General Features \\
\hline Sandstone & $>8$ & $>8$ & More than $79 \%$ sandstone \\
\hline Sand-shale & $>8$ & $8 / 1$ & More sand than shale; less than $11 \%$ limestone \\
\hline Shale--sand & $>8$ & $1-1 / 8$. & More shale than sand; less than $11 \%$ limestone \\
\hline Shale & $>8$ & $<1 / 8$ & More than $79 \%$ shale \\
\hline Sand-lime & $1-8$ & $>1$ & More sand than shale; 11 to $50 \%$ limestone \\
\hline Shale-lime & $1-8$ & $<1$ & More shale than sand; 11 to $50 \%$ limestone \\
\hline Lime-sand & $1 / 4-1$ & $>1$ & 50 to $80 \%$ limestone; more sand than shale \\
\hline Lime--shale & $1 / 4-1$ & $<1$ & 50 to $80 \%$ limestone; more shale than sand \\
\hline Limestone & $<1 / 4$ & any value & More than $80 \%$ limestone \\
\hline
\end{tabular}


Wafdy, et al

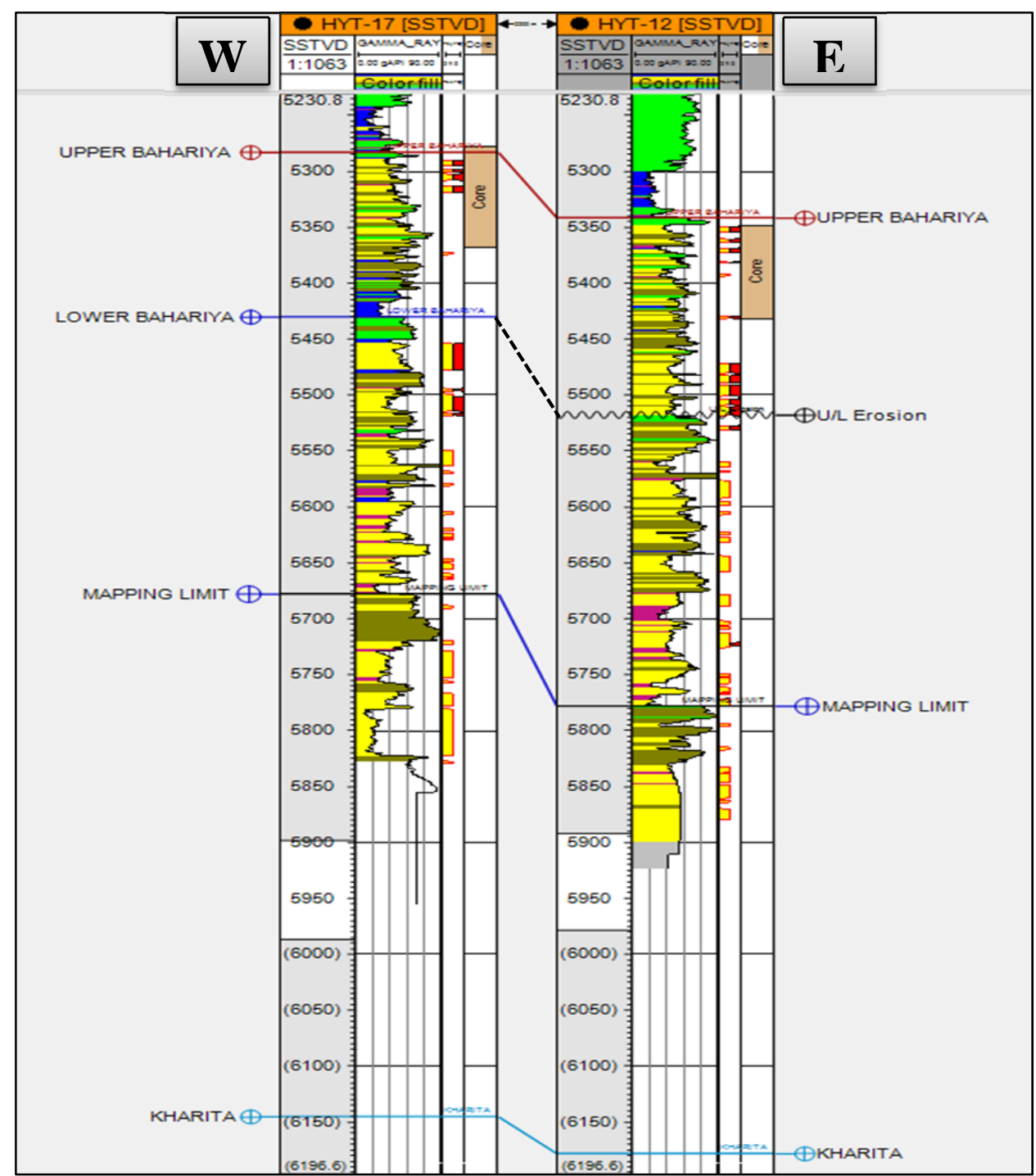

Fig. 5C:

Structural correlation passing through the profile B-B' (Fig.4) from west to east.

Fig. 6: Plotting of the lithologic components of the Upper Bahariya reservoir on the standard triangle Lithologic model.

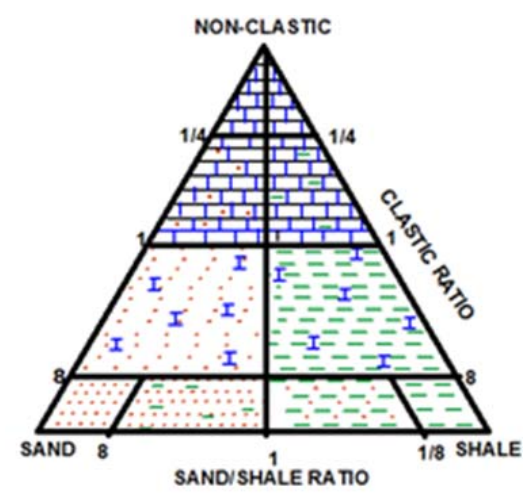

The sandstone isolith map of the Upper Bahariya (Fig. 7c) shows that the thickness of sandstone increases towards the central part of the study area in both Hayat-12 and Hayat-14 wells, where the channel adds to the Upper Bahariya sandstone thickness. It reaches the greatest thickness of about $94 \mathrm{ft}$. at Hayat-12 well, while the minimum thickness of $42 \mathrm{ft}$. is recorded at Yasser-06 well (Table 4) in the northeastern and northwestern parts of the study area. 
The subsurface geology and reservoir characteristics of the Upper Bahariya Reservoir

Table 3: Depths and thicknesses of the Upper Bahariya reservoir.

\begin{tabular}{||c|c|c|c||c||}
\hline \hline \multirow{2}{*}{ Well } & \multirow{2}{*}{ Reservoir } & \multicolumn{2}{|c|}{ Depth (ft) } & \multirow{2}{*}{ Thickness (ft) } \\
\cline { 3 - 4 } & & Measured & Subsea (-) & \\
\hline \hline \multirow{4}{*}{ Hayat-12 } & & 6067 & -5341 & $176 \mathrm{ft}$ \\
\cline { 4 - 5 } Hayat-14 & 6080 & -5369 & $163 \mathrm{ft}$ \\
\hline Hayat-17 & & -5283 & $147 \mathrm{ft}$ \\
\hline Yasser-06 & & 5928 & -5248 & $152 \mathrm{ft}$ \\
\hline
\end{tabular}

Table 4: Thickness, percentages and ratios of different facies encountered in the Upper Bahariya reservoirs.

\begin{tabular}{|c|c|c|c|c|c|c|c|c|c|}
\hline WELL & Reservoir & $\begin{array}{l}\text { Sandstone } \\
\text { (ft) }\end{array}$ & $\begin{array}{l}\text { Siltstone } \\
\text { (ft) }\end{array}$ & $\begin{array}{l}\text { Shale } \\
\text { (ft) }\end{array}$ & $\begin{array}{c}\text { Carbonate } \\
\text { (ft) }\end{array}$ & $\begin{array}{c}\text { Clastic } \\
(\%)\end{array}$ & $\begin{array}{c}\text { Non-Clastic } \\
(\%)\end{array}$ & $\begin{array}{c}\text { Sand/ Shale } \\
\text { Ratio }\end{array}$ & $\begin{array}{c}\text { Clastic/ } \\
\text { non-clastic } \\
\text { Ratio } \\
\end{array}$ \\
\hline Hayat-12 & \multirow{4}{*}{ 离彥 } & 94 & 54 & 19 & 9 & 94.9 & 5.1 & 1.29 & 18.56 \\
\hline Hayat-14 & & 91 & 48 & 14 & 9 & 94.4 & 5.6 & 1.47 & 17 \\
\hline Hayat-17 & & 53 & 49 & 17 & 28 & 81 & 19 & 0.80 & 4.25 \\
\hline Yasser-06 & & 42 & 55 & 32 & 23 & 84.9 & 15.1 & 0.48 & 5.61 \\
\hline
\end{tabular}

The shale isolith map of the Upper Bahariya (Fig. 7d) shows that the greatest thickness is $32 \mathrm{ft}$. at the northeast direction in Yasser-06 well. It decreases towards the southwest to about $14 \mathrm{ft}$, at Hayat-14 (Table 3). The thicknesses variation of shale may be due to the nature of sediment supply and/or structural conditions.

The clastic percentage map (Fig. 7e), shows an increase in the clastic percentage towards the central part of the study area. The non-clastic percentage map (Fig. 7f) shows that the non-clastic percentage increases in the study area towards the west and east directions.

Figure $7 \mathrm{~g}$, shows that the sand/shale ratio ranging from 0.5 to 1.5 with the values increasing in the central and southern parts of the study area; specially at Hayat-12 and Hayat-14 wells due to the presence of sandstone in the channel.

Generally, the constructed facies maps indicate that there is no dominant homogeneous lithological composition for the Upper Bahariya, but the lithology composition varies according to the local depositional environment extending over the study area.

\section{Thin section descriptions}

The microscopic investigations of the studied thin sections revealed the presence of the following rock types:

\section{Glauconitic calcitic subfeldspathic arenite rock type}

This rock type is observed at depth 6128'2" in Hayat-14 well (Fig. 8A). It shows moderately to well sorted, highly compacted and well cemented quartz grains (Q). Common partly oxidised and altered glaucony pellets $(\mathrm{Og})$ and chloritised glaucony $(\mathrm{Cg})$, minor detrital clay matrix $(\mathrm{Dc})$ and extensive pore filling and grain replacive ferroan calcite $(\mathrm{Fc})$. The reservoir quality is very poor due to the extensive carbonate cementation, detrital clays matrix and compacted galucony grains.

\section{Quartz wacke rock type}

This rock type (depth 6154'2"), Hayat-14 well shows moderately to well sorted, moderately compacted quartz grains $(\mathrm{Q})$, extensive grain coating and pore filling dispersed detrital clay matrix (Dc), minor oxidised galucony pellets $(\mathrm{Og})$, minor patchy pore filling ferroan dolomite (Fd) (Fig. 8B). The reservoir quality is very poor, most of the primary pores are occluded by detrital clay matrix.

\section{Subfeldspathic arenite rock type}

This rock type (depth 5949'2") Hayat-17 well. It composed of well sorted and well cemented quartz grains $(\mathrm{Q})$, commonly leached potasium feldspars $(\mathrm{Kf})$, rare pyrite aggregates $(\mathrm{P})$, very well 
Wafdy, et al

interconnected pore system dominated by interrparticle pores ( $\phi i$ ) (Fig. 8C). The reservoir quality is very good.
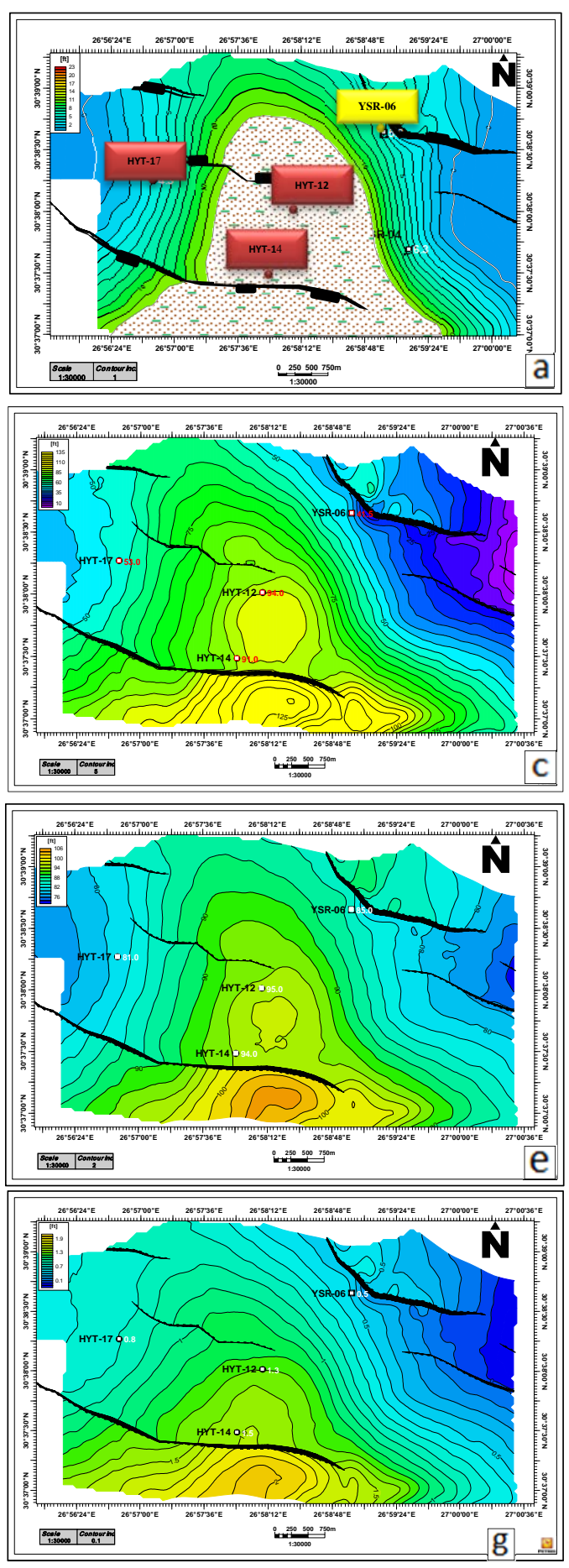
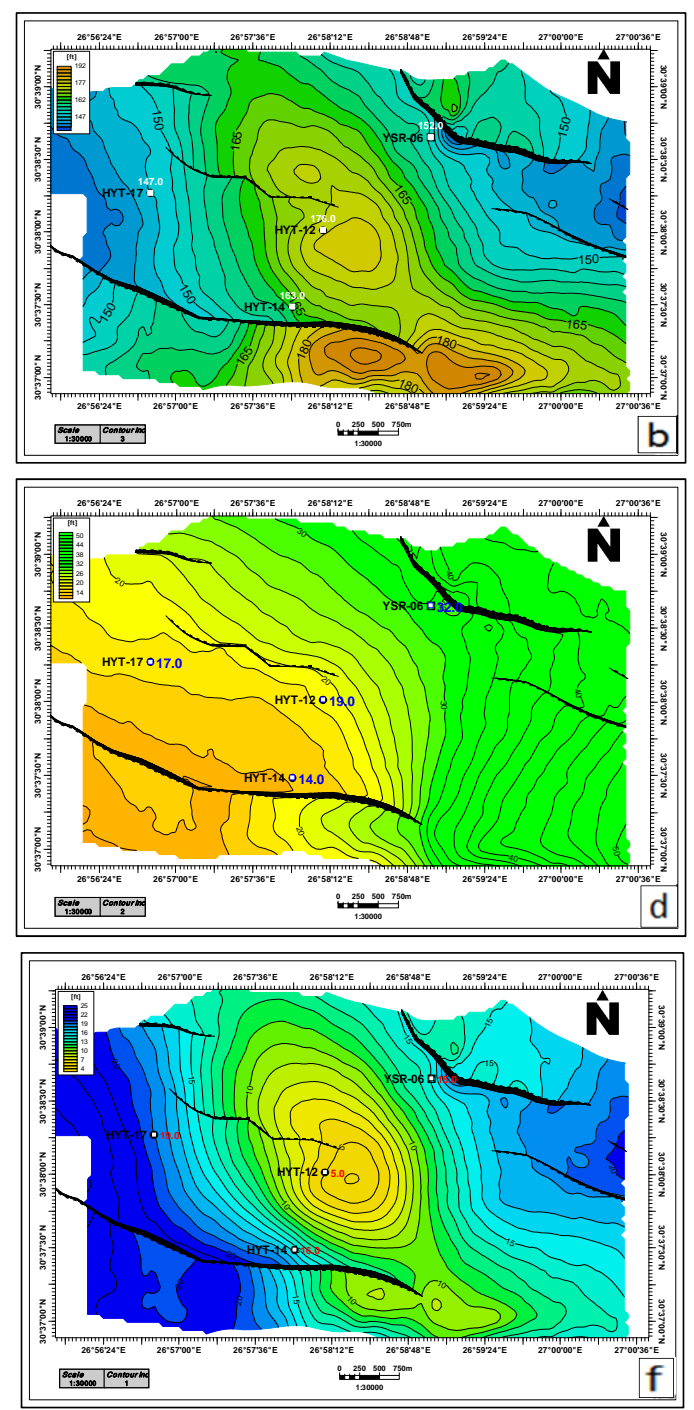

Fig. 7: Facies distribution maps of the Upper Bahariya reservoir (a) Lithofacies map, (b) Isopach, (c) Sandstone isolith, (d) Shale isolith, (e) Clastic percentage, (f) Non-clastic percentage, and (g) Sand/shale ratio maps of the Upper Bahariya Member.

\section{Subfeldspathic wacke rock type}

This Subfeldspathic wacke is recognized at depth 5989'1" in Hayat-17 well. It consists of the moderately to well sorted, well compacted quartz grains (Q), commonly leached potasium feldspars, and partialy oxidisd glaucony pellets $(\mathrm{Og})$. Minor partly pyritised carbonaceous matter that marks the burrow's outline $(\mathrm{Cm})$, and detrital clay matrix (Dc) (Fig. 8D). The pore system dominated by secondary intraparticle feldspar dissolution and less common interparticle, which illustrate the poor reservoir qulaity. 
The subsurface geology and reservoir characteristics of the Upper Bahariya Reservoir

\section{Phosphatic kaolinitic subfeldspathic arenite rock type}

It is recorded at depth 5945'7"in Yasser-06 well. This rock type is dominated by very poorly sorted and very well cemented detrital quartz grains (Q) (Fig. 8E). Abundant coarse to granule grade phosphatic fragments (bones, phosphatised shell fragments and claystone, fish tooth) $(\mathrm{Pb})$ are recorded with, patchy subcubic pyrite aggregates $(\mathrm{P})$ locally replacing phosphatic fragments $(\mathrm{Pb})$. Predominantly microcrystalline siderite $(\mathrm{Sd})$ is observed replacing the detrital clay matrix $(\mathrm{Dc})$. It contains very poorly developed secondary inter- and intraparticle porosity which reflect the poor reservoir quality performance.

\section{Argillaceous subfeldspathic arenite rock type}

This rock typr is obsered at depth 6150'2" in Hayat-12 well. It is made up of very well sorted, moderately to well cemented quartz grains $(\mathrm{Q})$, minor leached plagioclase feldspars $(\mathrm{Pl})$, oxidised glaucony pellets $(\mathrm{Og})$, locally patchy pore filling dispersed detrital clays $(\mathrm{Dc})$ that occasionally sideritised and grain replacive pyrite aggregates (P) (Fig. 8F). Moderate to well intreconnected pores dominated by interparticle pores $(\phi i)$, reflecting the good reservoir quality.

\section{Calcitic green sand rock type}

Calcitic green sand is observed at depth 6079'6" in Hayat-14 well. It consists of poorly to moderately sorted very well cemented quartz grain, Minor quantities of very fine grained detrital quartz grain (Q) (Fig. 8G). Abundant sub -to well rounded oxidised glaucony pellets (Og) with rare phosphatic/bone fragments $(\mathrm{Pb})$ are observed. Extensive grain replacive and pore filling ferroan calcite $(\mathrm{Fc})$ with subordinate quantities of ferroan dolomite $(\mathrm{Fd})$ are common. Very poor reservoir quality due to extensive carbonate cementation and compacted glaucony grains which reduce porosity and permeability.

\section{Subfeldspathic arenite rock type}

This Subfeldspathic arenite aqre recoreded at depth 6121'2"in Hayat-12 well. It made up of very well sorted, well cemented quartz grain $(\mathrm{Q})$, with minor potassium and plagioclase feldsapar (prbably completely leached (Pl) (Fig. 8H). Abundant very well developed syntaxial quartz overgrowth is observed. Moderate to well intrconnected pore system, dominated by interparticle pores ( $\phi \mathrm{i})$ and secondary intraparticle porosity with dissolution of plagioclase felsdspars $(\phi s)$, resulting in good reservoir performance.

\section{Depth 6128'2" (Hayat-14) (Glauconitic calcitic subfeldspathic arenite) (Fig. 9A).}

Moderately sorted, very fine lower grained, well cemented, common pore filling crystallised illitic/chloritic clay plates (Ic). Abundant poor- well developed quartz overgrowth (O), rare altered framework grains to well crystallized kaolinite clay booklets $(\mathrm{K})$. It is very rare to find the open primary intergranular porosity, most infilled by detrital clay, and lost due to a high degree of compaction (close grain packing), and the main porosity type is microporosity between pore filling illitic/chloritic clay plates with rare secondary feldspar dissolution porosity, resulting in very poor reservoir quality.

\section{Depth 5949'2" (Hayat-17) (Subfeldspathic arenite) (Fig. 9B).}

Well sorted, fine lower to fine upper quartz grained, abundant quartz $(\mathrm{Q})$, rare feldspar. No detrital clays are observed, abundant well developed quartz overgrowths $(\mathrm{O})$, very rare poorly crystallised illitic/chloritic pore lining plates (Ic). Open grain packing, with abundant open primary intergranular pores $(\phi i)$, and rare secondary feldspar dissolution. The reservoir quality is very good.

\section{Depth 5989'1" (Hayat-17) (Subfeldspathic wacke) (Fig. 9C).}

Well sorted, well cemented, highly compacted, very fine lower grained argillaceous sandstone. Abundant quartz (Q), rare feldspar and mica. Abundant pore filling chloritic/illitic (Ic), poorly crystallised clay plates mixed with poorly crystallised kaolinite clay booklets $(\mathrm{K})$. The bulk of the primary intergranular porosity infilled by chloritic/illitic clay plates and rare secondary feldspar dissolution referred to very poor reservoir quality. 
Wafdy, et al
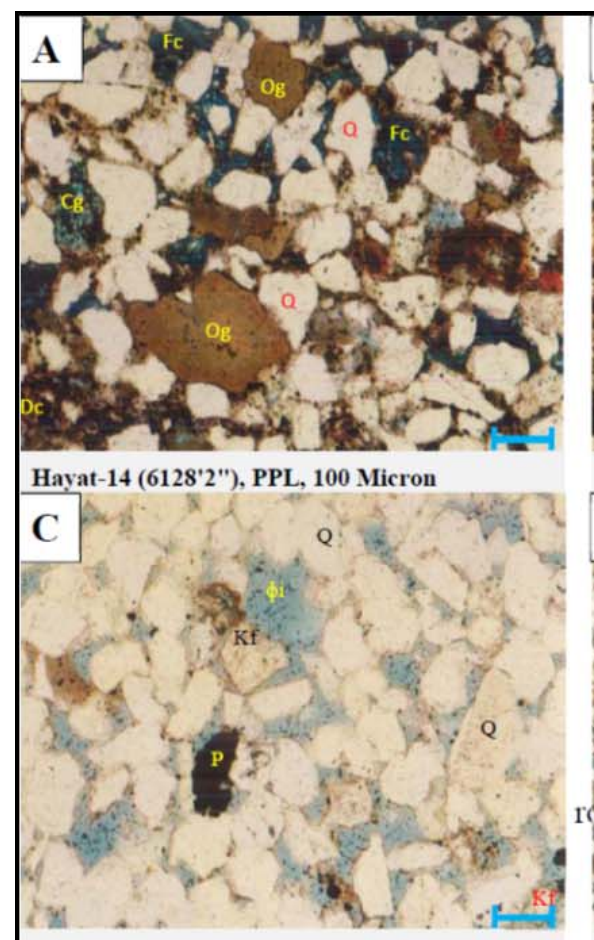

Hayat-17 (5949'2"), PPL, 100 Micron
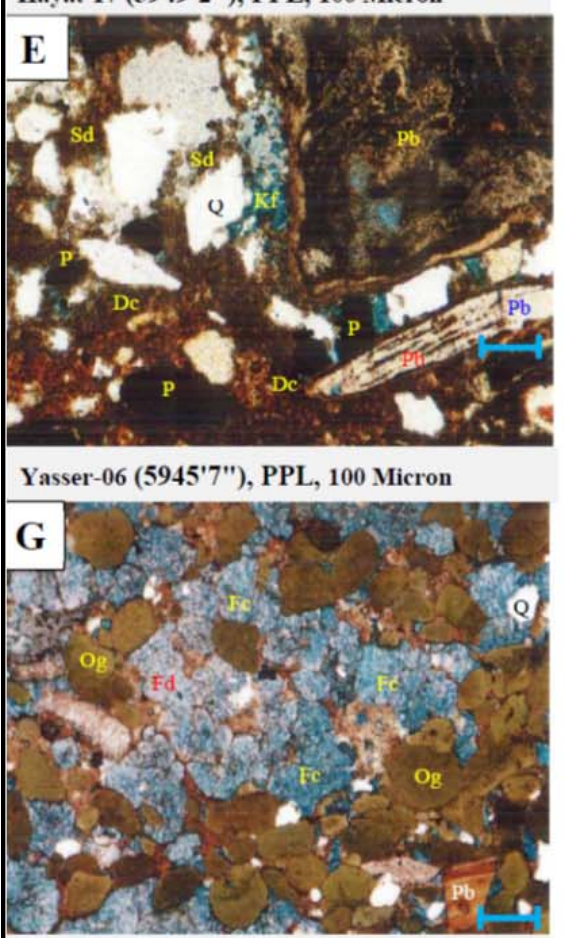

Hayat-12 (6079'6"), PPL, 260 Micron
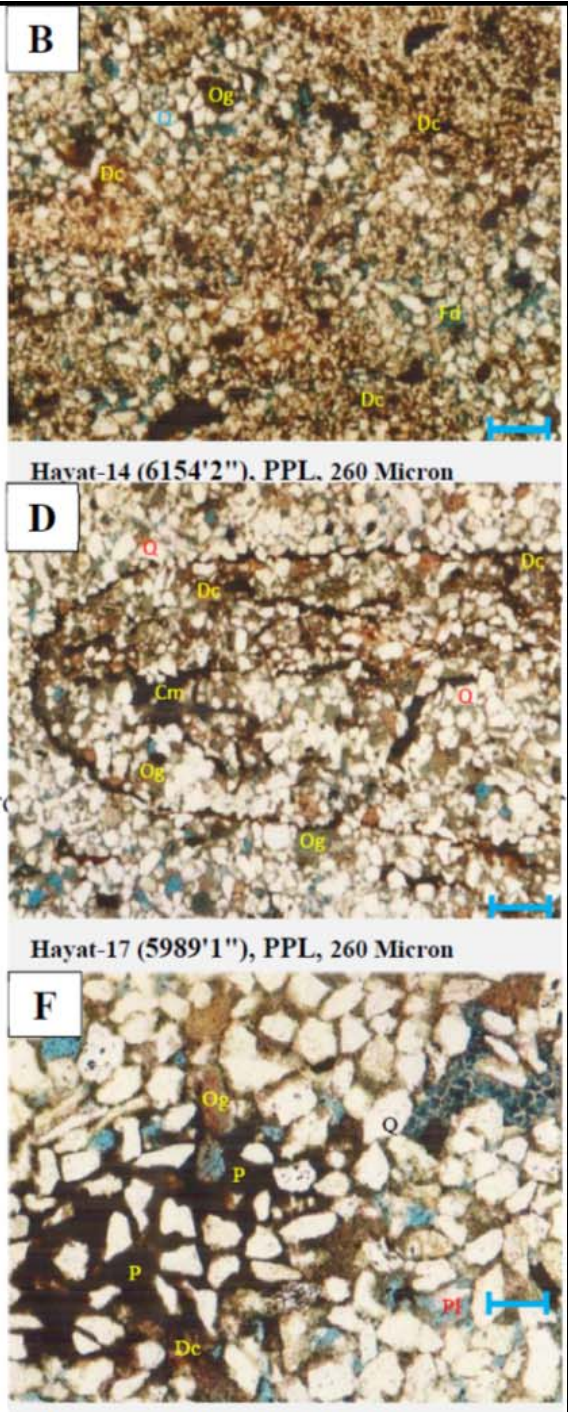

Hayat-12 (6150'2"), PPL, 100 Micron

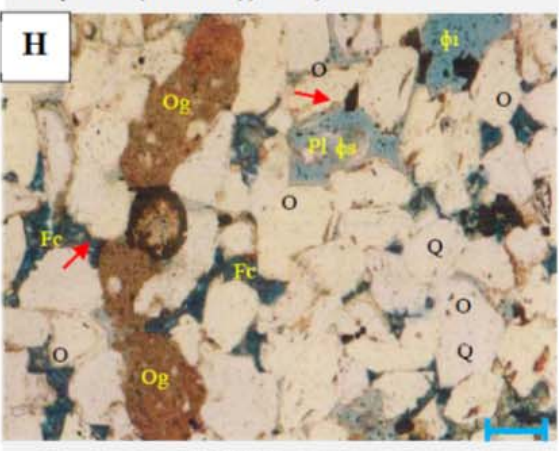

Hayat-12 (6121'2"), PPL, 100 Micron
Fig. 8: Photomicrographs of the recorded rock types in the Upper Bahariya reservoir.

\section{Depth 6150'2" (Hayat-12) (Argillaceous subfeldspathic arenite) (Fig. 9D).}

Well sorted, very fine upper quartz grained, well cemented, with rare feldspars (partial to complete leached out), rare poorly crystallised illitic/chloritic clay plates (Ic) locally infill the primary intergranular pores. Common moderately to well-developed quartz overgrowth $(\mathrm{O})$.

Moderate open primary intergranular pores $(\phi \mathrm{i})$ locally infilled by poorly crystallised illitic/chloritic clay plates, with secondary feldspar dissolution $(\mathrm{Pl})$ porosity $(\phi \mathrm{s})$, resulting in moderate reservoir quality. 
The subsurface geology and reservoir characteristics of the Upper Bahariya Reservoir

Depth 6121'2" (Hayat-12) (Subfeldspathic arenite) (Fig. 9E).

Very well sorted, fine lower quartz grained, well cemented, with rare feldspars (partial to complete leached out), clean sand, no obvious detrital clay. Rare poorly crystallised illitic/chloritic clay plates (Ic) locally infill the primary intergranular pores. Common moderately to well-developed quartz overgrowth $(\mathrm{O})$. Abundant open primary intergranular pores $(\phi \mathrm{i})$, with secondary feldspar dissolution porosity $(\phi \mathrm{s})$ (feldspar grains; Pl), resulting in very good reservoir quality.

Fig. 9: Scanning electron micrographs of some selected rock types in the studied Upper Bahariya reservoir.

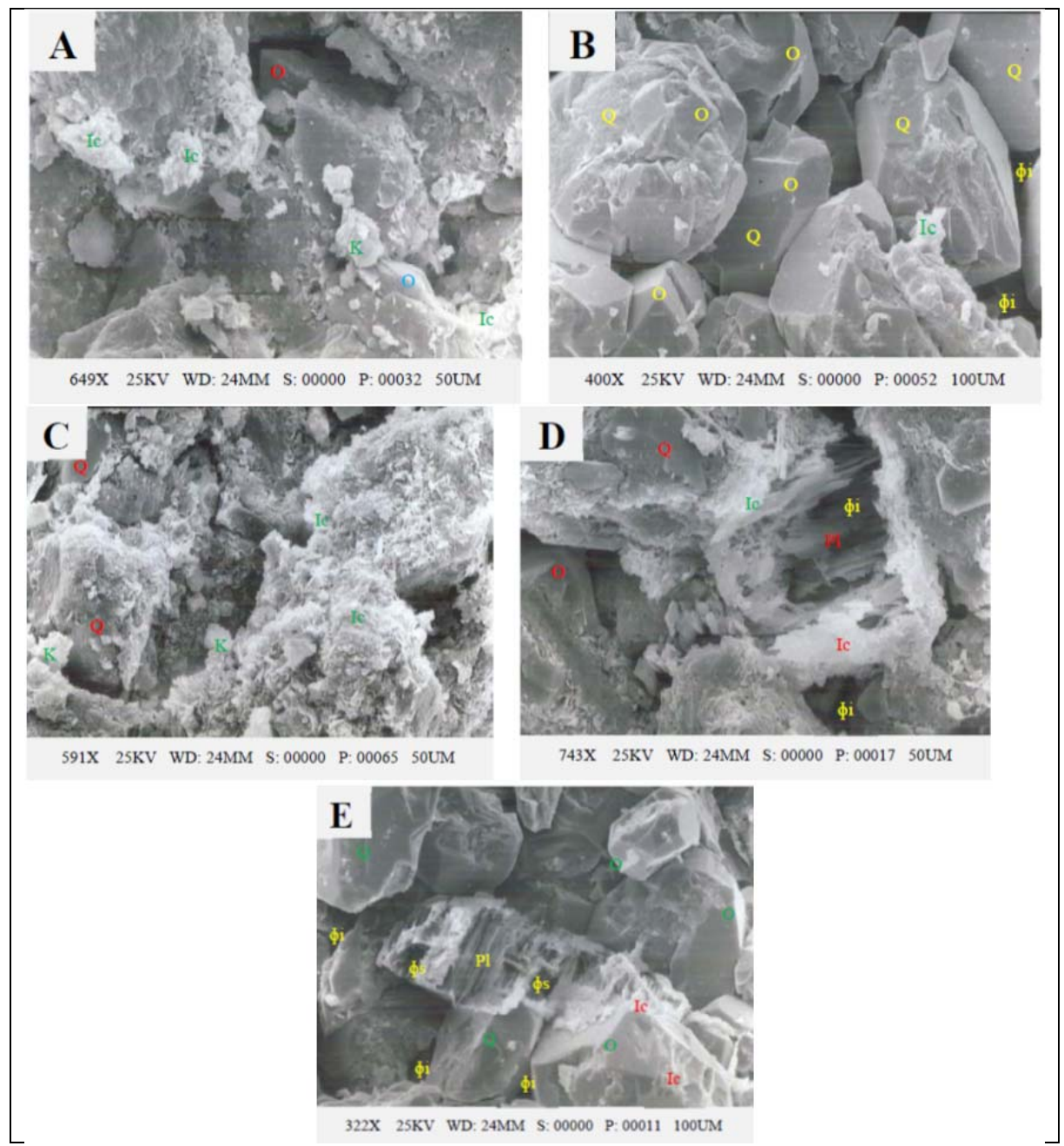

\section{Upper Bahariya petrophysical litho-saturation cross plot:}

The vertical analysis of the Upper Bahariya in Yasser-06 using Neutron-Density logs shows a mixed lithology of shale, siltstone, sandstone, and some streaks of limestone and dolomite; sandstone increase in the middle part of the Upper Bahariya reservoir (Fig. 10). The average effective porosity is $19.28 \%$; the middle part of the formation is characterized by the presence of considerable hydrocarbon saturation. The average value of movable hydrocarbons is $29.49 \%$, whereas the average value of residual hydrocarbons is $33.62 \%$. The other parts of the formation are fully saturated with water where hydrocarbons are rare. Therefore, hydrocarbon productivity is expected from the middle two sandstone zones at depths 5921$5927 \mathrm{ft}$ and 5984-5990 ft.In Hayat-12, the litho-saturation cross plot (Fig. 11), illustrates that the Upper Bahariya is composed primarily of sandstone with layers of shale and siltstone and streaks of carbonate. The sandstone lithology increase is due to the presence of a channel fill sandstone that cuts the basal part of the Upper Bahariya and top part of Lower Bahariya. The effective porosity is $20.69 \%$ in the upper and lower zones that contain high sandstone percentages. The fluid analysis of the formation indicates that hydrocarbon saturation is high over the sandstone zones. The movable hydrocarbons reach $35.67 \%$ on average, while the residual hydrocarbons amount to $42.44 \%$. 
Figure 12, shows the studied interval in the Hayat-14 well. The Neutron-Density shows a mixed lithology of shale, siltstone and sandstone, with some carbonate streaks. Sandstone increases in the upper part of the well where the average effective porosity is relatively low, reaching about $16.65 \%$. Fluid analysis indicates that the upper part of the formation is characterized by a hydrocarbon saturation of about $52.51 \%$. The average movable hydrocarbon value is $12.57 \%$ while the average value of residual hydrocarbon is $39.94 \%$. The basal part of the Upper Bahariya Formation at Hayat-14 is eroded by the same channel that is present in Hayat-12, but the sandstone is highly argillaceous and very tight so not calculated as a reservoir.In Hayat-17 (Fig. 13), the analysis illustrates a mixed lithology of shale, siltstone and sandstone, with some streaks of carbonate in the basal part of the formation. The main sandstone bodies at the top of the formation have a predominance of shale in the middle zone. The average effective porosity is $18.30 \%$. Fluid analysis indicates that the upper part of the formation is characterized by high hydrocarbon saturation. The average movable hydrocarbon value is $31.81 \%$ while the average value of residual hydrocarbon is $30.67 \%$.

Table. 5: Vertical track legend used in figures 10-13 "classification and abbreviation used in this study".

\begin{tabular}{|c|c|c|c|c|c|}
\hline Track Number & Track Name & Scale & Unit & Symbol & Description \\
\hline \multirow{3}{*}{1} & GR & $0-150$ & API & & Gamma Ray curve \\
\hline & CALI & $6-16$ & Inches & & Caliper \\
\hline & BS & $6-16$ & Inches & $=$ & Bit size \\
\hline 2 & Depth & & FT & & Depth \\
\hline 3 & Fm tops & & & & Formation Top \\
\hline \multirow{3}{*}{4} & RT & $0.2-2000$ & ohm.m & & Deep resistivity \\
\hline & IMPH & $0.2-2000$ & ohm.m & ---- & Medium resistivity \\
\hline & MSFL & $0.2-2000$ & ohm.m & & Micro-spherical resistivity \\
\hline 3 & Depth & & FT & & Depth \\
\hline 4 & Fm tops & & & & Formation Top \\
\hline \multirow{4}{*}{5} & RHOB & $1.95-2.95$ & & - & \\
\hline & NPHI & $0.45--0.15$ & & ---- & \\
\hline & $\mathrm{PE}$ & $0-20$ & & & \\
\hline & DRHO & $-0.75-0.25$ & & & \\
\hline \multirow{2}{*}{6} & RESF & $0-2$ & & & \\
\hline & PAYF & $2-0$ & & & \\
\hline \multirow{2}{*}{7} & SW & $1-0$ & & & \\
\hline & SXO & $1-0$ & & & \\
\hline \multirow{3}{*}{8} & PHIE & $0.5-0$ & & & \\
\hline & BVWSXO & $0.5-0$ & & & \\
\hline & BVW & $0.5-0$ & & E & \\
\hline \multirow{5}{*}{9} & \multirow{5}{*}{ Lithology } & \multirow{5}{*}{$\begin{array}{c}\text { Cumulative } \\
\text { volumes }\end{array}$} & & & Dolomite \\
\hline & & & & 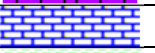 & Limestone \\
\hline & & & & 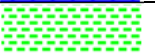 & Shale \\
\hline & & & & $=0$ & Siltstone \\
\hline & & & & $\because \because$ & Sandstone \\
\hline
\end{tabular}

\section{SUMMARY AND CONCLUSIONS}

The petrographic aspects of the penetrated sandstone-dominated sequences of the Upper Bahariya have been determined by detailed microscopic examination of some selected samples (core chips) from four wells; Hayat-12, 14, 17, and Yasser-06. The petrographical characteristics have been identified using thin sections (8 samples) and SEM analysis (5 samples). These analyses revealed that the main microfacies rock types are glauconitic calcitic subfeldspathic arenite, quartz wacke, subfeldspathic arenite subfeldspathic wacke, phosphatic kaolinitic subfeldspathic arenite, argillaceous subfeldspathic arenite, and calcitic green sand. Cement types are variable (kaolinite, calcite, ferroan calcite and ferroan dolomite, and silica overgrowth), that could help in the distinction of the rock types. 
The subsurface geology and reservoir characteristics of the Upper Bahariya Reservoir

Fig. 10: Litho-

Saturation

Cross Plot of the Upper

Bahariya reservoir in Yasser-06.
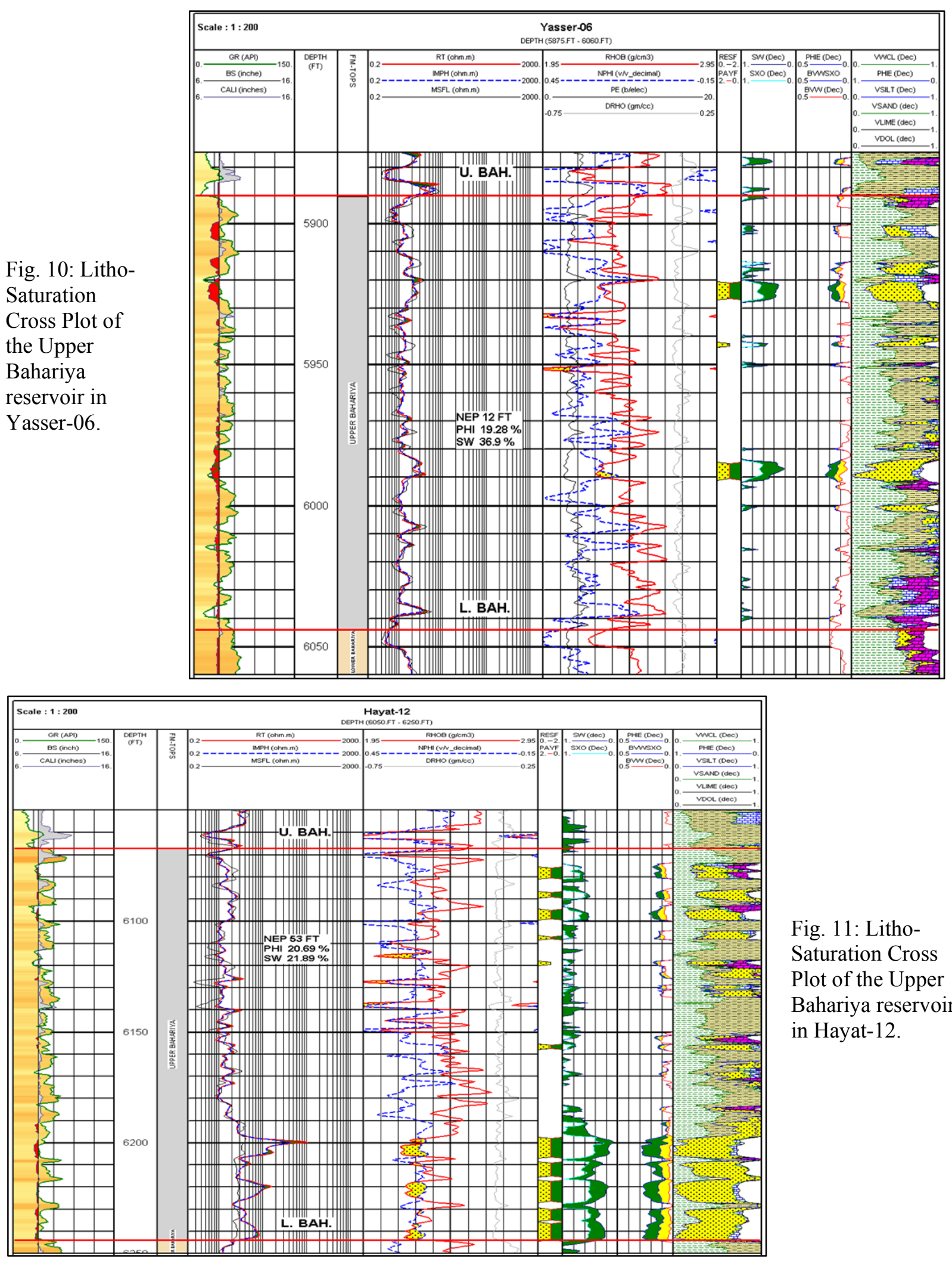

Fig. 11: LithoSaturation Cross Plot of the Upper Bahariya reservoir in Hayat-12. 
Wafdy, et al

Fig. 12: LithoSaturation Cross Plot of the Upper Bahariya reservoir in Hayat-14.
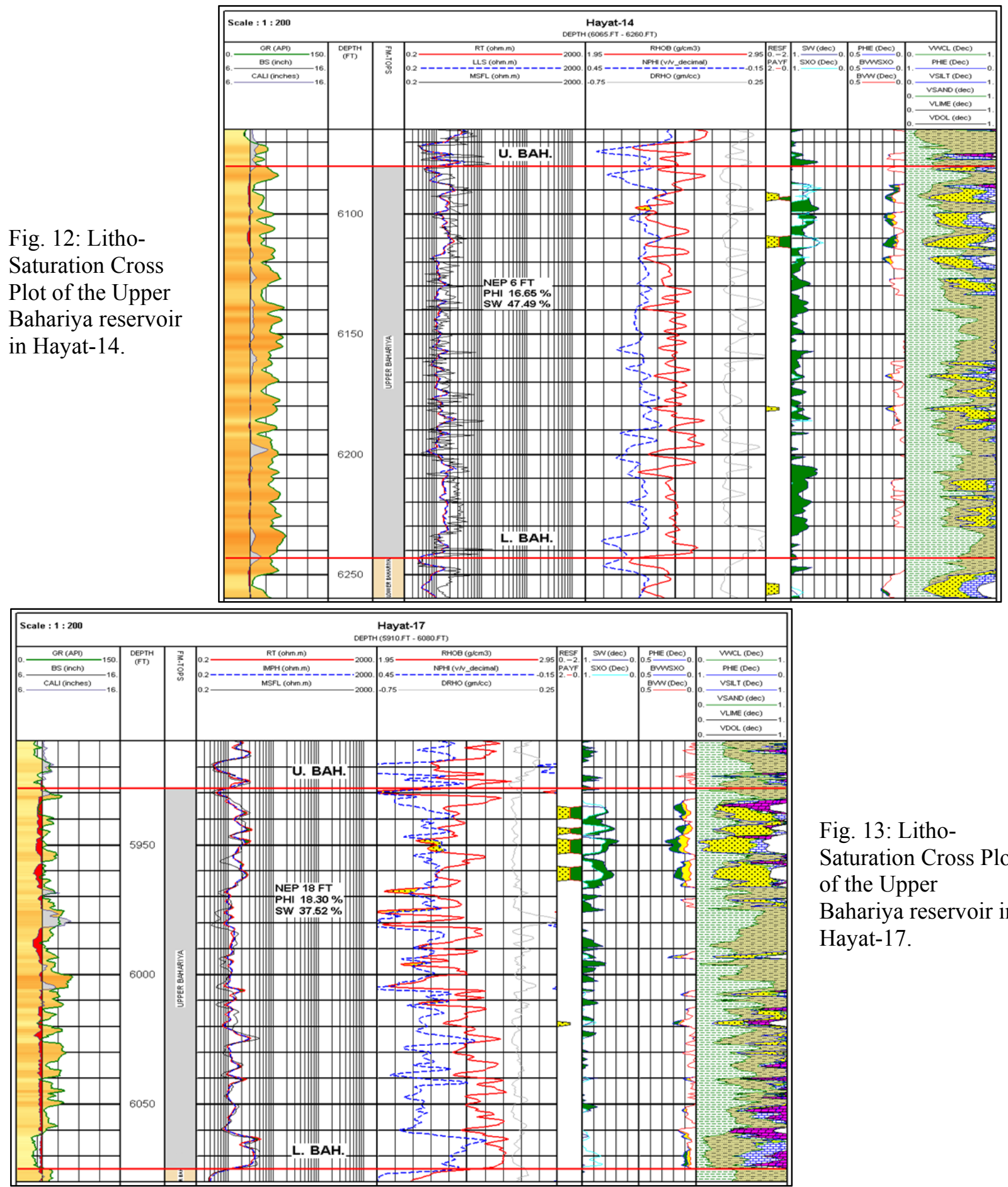

Fig. 13: Litho-

Saturation Cross Plot of the Upper

Bahariya reservoir in Hayat-17.

-The main framework components are detrital quartz grains, ranging in size from pebble at the lower part to fine sand size and silt. Matrix is mainly clay and quartz silt grains with glaucony pellets, cement of authigenic and secondary mineral filling

-Pore spaces of intergranular types in some cases are preserved open. The reservoir sandstones are mostly subfeldspathic arenite with abundant quartz overgrowths and glaucony, and subordinate chlorite, kaolin, and illite. 
The subsurface geology and reservoir characteristics of the Upper Bahariya Reservoir

-The SEM agreed with the thin section description and interpretation chlorite occurrence is associated with glaucony and plagioclase. Subordinate occurrence of illite in samples either as replacive of detrital clays, dissolution of feldspars and glaucony or bridging pore in between locally replaced kaolinite plates has little contribution to reservoir quality. Illite has platy morphology with occasional short fibrous projections texture.

-From the previous petrographical and petrophysical analysis we noted that the reservoir potential is very good and the porosity is highly effective in the subfeldspathic arenite samples, with reservoir quality moderate to high. This reflected from the petrophysical log calculation at reservoir flag depths.

\section{REFERENCES}

Amin, M. S., (1961): Subsurface features and oil prospects of the Western Desert, Egypt. $3^{\text {rd }}$ Arab. Petrol. Cong., Alexandria, Egypt, 2, 8.

Bevan, T.G., Moustafa, A.R., 2012. Inverted rift-basins of northern Egypt: phanerozoic rift systems and sedimentary basins. In: Roberts, D., Bally, A. (Eds.), Regional Geology and Tectonics, 2, 483-506.

Bosworth, W., El-Hawat, A.S., Helgeson, D.E., Burke, K., (2008): Cyrenaican "shock absorber" and associated inversion strain shadow in the collision zone of northeast Africa. Geology 36, 695e698.

Darahem, M., Paradisi, G., and Moinard, L. (1990): Evaluation of the Bahariya Formation from high resolution logging. In 10th EGPC Explor. and Prod. Seminar (290-315).

Dia El Din, M. (1974): Stratigraphic and structural studies of Abu Gharadig oil and gas field. In Proceed. $4^{\text {th }}$ EGPC Explo. Seminar.

Dolson, J. C., Shann, M. V., Matbouly, S. I., Hammouda, H., Rashed, R. M., (2001): Egypt in the twentyfirst century: petroleum potential in offshore trends. GeoArabia 6, 211-230.

El Gazzar, A. M., Moustafa, A. R. and Bentham, P., (2016): Structural evolution of the Abu Gharadig field area, northern Western Desert, Egypt. Journal of African Earth Sciences, 124, 340-354. doi.org/10.1016/j.jafrearsci.2016.09.027

El Sheikh, M. (1990): Reservoir geology of Bahariya Formation in the Meleiha development lease. In 10th EGPC Petrol. and Prod. Conf., 15.

Emam, A., Bishopp, D.J., Milsom, J., Dunderdale, I., (1990): The structural setting of the central Western Desert, Egypt. In: Proceedings of 10th Egyptian General Petroleum Corporation Petroleum Exploration and Production Conf., 2, 30-70.

Hantar, G. (1990): North Western desert. Geology of Egypt, 293-327.

Kerdany, M. T., and Cherif, O. H. (1990): Mesozoic. In Said (Edit) the geology of Egypt (pp. 407-438).

Kholeif, W., Work, J. G., and Sanad, S. (1986): Meleiha, its history and its significance. EGPC 86th Exploration and Production Conference, Cairo, Egypt. Egyptian General Petroleum Corporation Bulletin, 1, p. 13.

Krumbein, W.C. and Sloss, L.L. (1963) Stratigraphy and Sedimentation (2nd edn). W.H. Freeman, San Francisco.

Meshref, W. M. (1982): Regional structural setting of northern Egypt. In Proceeding of the 6th Egyptian general petroleum corporation exploration seminar, Cairo (pp. 17-34).

Meshref, W. M. (1996): Cretaceous tectonics and its impaction on oil exploration in regional Northern Egypt. 'Review Geol. Soc. Egypt, 2(Spec. Publ.), (pp. 199-241).

Metwalli, M. H., Saad, M. K., and Ali, T. A. (2000): Effect of depositional environments on reservoir capacity of upper Bahariya Formation, Meleiha oil fields, north Western Desert, Egypt. Sedimentology of Egypt, 8, 105-118.

Moussa, S. (1986): Evolution of the sedimentary basins of the North Western Desert, Egypt. In Proceedings of the EGPC 8th Exploration and Production Conference, Cairo. Egyptian General Petroleum Corporation Bull., 1, 66-84.

Moustafa, A. R., Khalil, M. H., (1990): Structural characteristics and tectonic evolution of north Sinai fold belts. In: Said, R. (Ed.), The Geology of Egypt. A. A. Balkema, Rotterdam, pp. 381 e389.

Moustafa, A. R., (2008): Mesozoic-Cenozoic basin evolution in the northern western desert of Egypt. Geol. East Libya 2008, 3, 29-46.

Norton, P. (1967): Rock stratigraphic nomenclature of the Western Desert. Egypt. Int. Report of GPC, Cairo, Egypt, p. 557. 


\section{Wafdy, et al}

Parker, J. R. (1982): Hydrocarbon habitat of the Western Desert, Egypt. In Proceedings of the EGPC $6^{\text {th }}$ Exploration and Production Conf., Cairo. Egyptian General Petroleum Corporation Bull. 1, 24.

Said, R. (1990): Geology of Egypt. A. A. Balkema/Rotterdam /Brookfield, p. 733.

Said, R. (1962): Geology of Egypt. Elsevier Publ. Co., Amsterdam, p 370.

Salah, M. and Paradisi, C. (1992): Analysing Depositional Environments in Bahariya Formation Using High Resolution Electrical Image Data. 11th EGPC Exploration Production Conf., 2, 295-309.

Schlumberger (1995): Well evaluation conference, Egypt, p. 87.

Sestini, G. (1984): Tectonic and sedimentary history of the NE African margin (Egypt-Libya). Geological Society, London, Spec. Publ., 17(1), 161-175.

Shalaby, M. R., Abdel-Hameed, A. T., El-Awady, M. M., and Abu Shady, A. N. (2000): Structural setting and sedimentary environments using dipmeter analysis of some Jurassic reservoirs, North Western Desert, Egypt. In 5th International Conference, Geology of the Arab World, 217-220.

Sultan, N., Halim, M. A., (1988): Tectonic framework of northern western desert, Egypt and its effect on hydrocarbon accumulations. In: Proceedings of the 9th EGPC Petroleum Conf., Cairo, 2, 1-22.

Taha, M. A., (1992): Mesozoic rift basins in Egypt: their southern extension and impact on future exploration. In: Proceedings of the $11^{\text {th }}$ EGPC Petroleum Conf., 2, 1-19. 
The subsurface geology and reservoir characteristics of the Upper Bahariya Reservoir

الجيولوجيا السطحية وخصائص الخزان في عضو البحرية العليا في حقل نفط حياة / ياسر، شمال الصحراء الغربية، مصر

$$
\text { رضا الوافدي ا و سالم سليم ب و احمد ابو خضرهץ }
$$

ا شركة خالاه للبترول ، ب كلية العلوم ، جامعة القاهره

\section{الخلاصة}

إن القطاعات العرضية والتغير في سمك وسحنات خزان البحرية (عضو البحرية العلوي) تمت مناقثته وذلك من خلال تحليل إمتداد وبيئة الترسيب لعضو البحرية العليا داخل حوض الترسيب. وتبين من الدراسة أن قمة متكون خزان البحرية العليا في بئر

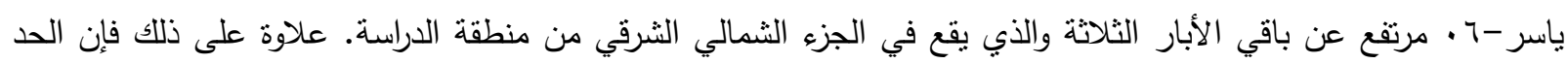

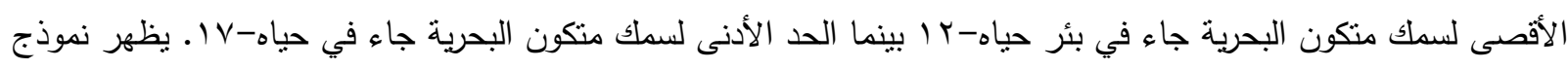

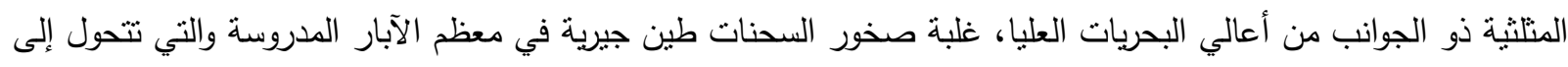

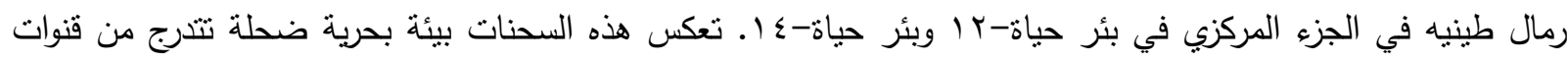

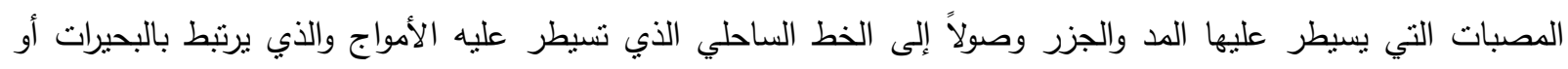
الخلجان. يوضح تحليل دراسة البنروغرافيا أنه يوجد تباين في جودة الخزان بناءا على مكونات الطين وعمليات مابعد الترسيب. 